\title{
Impact of Mining Activities on Water Resources in the Vicinity of the Obuasi mine
}

\author{
T. M. Akabzaa1 ${ }^{1 *}$, B. K. Banoeng-Yakubo ${ }^{1}$ and J. S. Seyire ${ }^{2}$ \\ ${ }^{1}$ Department of Geology, P. O. Box LG 58, University of Ghana, Legon, Ghana \\ ${ }^{2}$ Environmental Protection Agency (EPA), Accra, Ghana \\ *Corresponding author; E-mail: tabazaa@ug.edu.gh
}

\begin{abstract}
Surface and groundwater samples within the catchment area of the Obuasi mine were analysed to assess the impact of mining activities on water resources. The concentration of $\mathrm{Fe}, \mathrm{Mn}, \mathrm{Cu}, \mathrm{Zn}, \mathrm{Pb}, \mathrm{Cd}, \mathrm{Hg}, \mathrm{As}$ and selected major ions in water samples were analysed to assess their role in the contamination of both surface and ground water. The mineralogical composition of various mine spoil and rock samples was investigated by microprobe analysis to ascertain the possible sources of the metals in drainage and ground water. The hydrochemical analytical study, using standard methods, shows that streams in the study area have higher trace and major ions loading than ground water with iron and arsenic concentrations ranging from $0.025 \mathrm{mg} / \mathrm{l}$ to $17.19 \mathrm{mg} / \mathrm{l}$ and $<0.001 \mathrm{mg} / \mathrm{l}$ to $18.91 \mathrm{mg} / \mathrm{l}$, respectively. Hydrochemical modeling of water types showed varied composition for both ground and surface water, but with strong indication of mixed waters from a variety of sources. The microprobe results showed that waste rocks and related mine spoil contain a variety of $\mathrm{Fe}, \mathrm{Cu}, \mathrm{As}, \mathrm{Sb}, \mathrm{Zn}$ and co-bearing sulphides with strong compositional variations, and account for the augmented levels of these metals in drainage proximal to mining and processing facilities. The probe results did not show $\mathrm{Hg}$ in mine spoil, and very high $\mathrm{Hg}$ values observed in the vicinity of areas of intense illegal smallscale mining are attributed to the use of this chemical by miners in gold amalgamation.
\end{abstract}

\section{Introduction}

The study area is within the mining lease of the Ashanti Goldfields (Obuasi) Limited, and situated $160 \mathrm{~km}$ northeast of Accra. The Obuasi mine has been in operation for the past 110 years and can be described as the single industrial hub of the Ghanaian economy. It has produced in excess of 30 million ounces of gold since its inception and accounts for over $60 \%$ of the total national gold production. Its inventory of global resources is estimated in the neighborhood of 80.8 million tons at $8.1 \mathrm{~g} / \mathrm{t}$ (Gyapong \& Amanor, 2003).

The mine has undergone extensive expansion and modernization in the last two decades resulting in the development of extensive open pit mines and increased underground mining operations boosted by the development of a mosaic of new shafts. There has also been modernization of the processing technology used in the mine, with the introduction of hydrometallurgy and bio-oxidation technologies and gradual phase-out of pyrometallurgical processing up to 2000, in a move to reduce environmental pollution. The area also has a long history of native mining. Artisanal mining has been recorded in the area as early as 1471 (Kesse, 1985). Currently, active artisanal mining is intense in the area, but conducted by illegal miners, since the entire area is covered by the concession of Ashanti Goldfields.

The development of extensive mining operations in an area that can be described as ecologically sensitive zone, covered by forested highlands rising up to $400 \mathrm{~m}$ above sea level in some places and well-developed drainge system would certainly give rise to environmental problems. The changes from pyrometallurgy to hydrometallurgy and bio-oxidation were aimed at minimizing some of these environmental problems associated with the mineralogy of the ore. Environ-mental monitoring data obtained from water quality, mineralogical and gecochemical studies have been limited to the vicinity of these processing facilities and ore, respec-tively (Amonoo-Neiser \& Busari, 1980; Jetuah, 1997; Carbo \& Sarfo-Armah, 1997; Clement et al., 1997).

There is paucity of literature on specific geological controls on natural and mine water and their impacts on water resources in the area. The paper examines the mineralogical assemblages 
in mine spoil and rocks hosting toxic heavy metals as possible sources of these metals in drainage and ground water in the area, and assesses the impact of mining including illegal artisanal mining activities on water resources in the Obuasi township and its satellite communities (Fig.1).

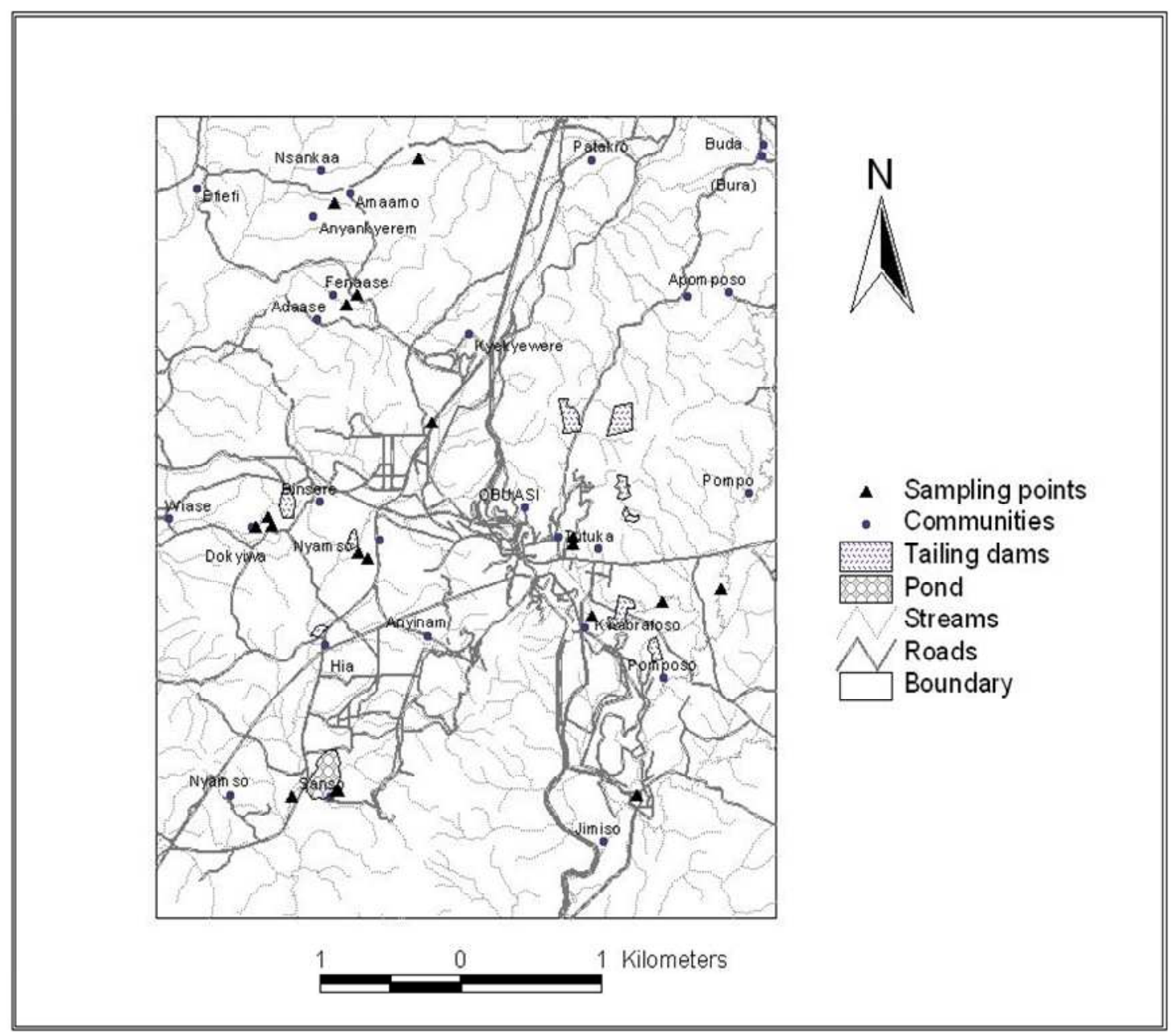

Figure 1: Map of Study Area showing sampling points.

\section{Geological setting}

The geology of the Obuasi mine has received considerable attention (Junner, 1932; Gyapong, 1980; Kesse, 1985; Bowell, 1993). The deposit is located in Birimian metavolcanics and metsedimentary rocks. Bedded and altered dark gray and black phyllite and sericite schist dominate the metasediments with quartz, sericite, and carbonates making up the bulk of mineralogy of these metasediments. The metavolcanics represent concordant flows within the metsedimentary pile (Hirdes \& Leube, 1989) that are intruded by contemporaneous and post tectonic granitoids. The volcanic units are largely tholeitic in character that have been subjected to greenschist metamor-phism. Mineralogically, they are dominated by carbonate, chlorite, albite, sericite quartz, leucoxene and epidote.

Structurally, mineralisation conforms to a general strike of NNE-SSW. Multiple deformational events have produced pervasive shear zones, striking between north and NE, and dipping at fairly high angles on either side of the vertical plane. These zones acted as channels for gold laden 
solutions (Gyapong, 1984). These multiple deformational regimes are believed to account for four distinct mineralization types at the mine: quartz vein mineralization, disseminated sulphides mineralization, granitoid mineralisation and supergene-enriched oxide ores (Gyapong \& Amanor, 2003). It is the quartz veins and the oxide ores that are very amenable to mining and mercury amalgamation by illegal miners in the area.

\section{Materials and methods}

Two different media were sampled in the study: rock samples were taken from mainly mine spoil heaps to assess their sulphide mineralogy, principal custodians of heavy metals and water from streams, boreholes and hand-dug wells were collected to evaluate heavy metal status and other water quality parameters. A total of 30 samples from the different media were taken with the following distribution: five rock samples and 25 water samples comprising 12 from boreholes, 10 from streams and three from hand-dug wells.

The collection, preservation, storage and preparation protocols of water samples followed those outlined in APHA (1998) and elaborated by Eppinger et al. (2000) for major ion and trace element determination. For water sampling, polyethylene bottles were rinsed three times with the water to be sampled prior to sampling. The analyses were performed at the Water Research Institute of the Council for Scientific and Industrial Research, and followed standard methods.

Rock samples were examined in hand specimens and appropriate areas of interest marked for polished thin section for mineralogical and chemical studies using transmitted and reflected light microscopy and electron microprobe analysis, respectively. Phase and textural relations among sulphides, carbonates and silicates were noted during microscopy and electron microprobe examination. The analysis was conducted at the Geological Institute of the University of Copenhagen, Denmark, using a JOEL JXA- 8200 WD/ED Supermicrobe combined micro analyzer operating at $20 \mathrm{KeV}$ with $10 \mu \mathrm{m}$ beam resolution and wave dispersion (WD) length of $11 \mathrm{~mm}$. Each spectrum was acquired in 20 seconds. Standard reference materials were used to calibrate the instrument for quantitative analysis of sulphides, carbonates and silicates.

\section{Results and discussion}

The results demonstrate significant variation in the concentration of the determined metals in water samples. Microprobe investigations revealed varied sulphide mineralogical assemblages with strong compositional variation arising from the incorporation of potentially toxic trace metals which also had strong finger prints in drainage waters.

\section{Water}

The hydrochemical analytical results show that streams in the study area are more polluted than groundwater. Groundwater is generally benign with only iron and arsenic values exceeding the maximum permissible WHO guide values in one sample in the case of iron and in four samples in the case of arsenic. Concentrations of iron and arsenic in groundwater range from below detection to $15.34 \mathrm{mg} / \mathrm{l}$ and $0.801 \mathrm{mg} / \mathrm{l}$, respectively (Table 1). Concentrations of the measured parameters in water from streams are much higher than in groundwater and are several orders of magnitude above the WHO permissible maximum guidelines for these parameters in water except for zinc and copper.

TABLE 1

Water quality parameter status in groundwater water in ( $\mathrm{mg} / \mathrm{l})$ except otherwise stated

$\begin{array}{lcccccc}\text { Parameter } & \text { Mean } & \text { Median } & \begin{array}{c}\text { Standard } \\ \text { deviation }\end{array} & \text { Min } & \text { Max } & \begin{array}{c}\text { WHO max. } \\ \text { guide value }\end{array} \\ \mathrm{Fe} & 1.343 & 0.044 & 3.938 & 0.019 & 15.340 & 0.3\end{array}$




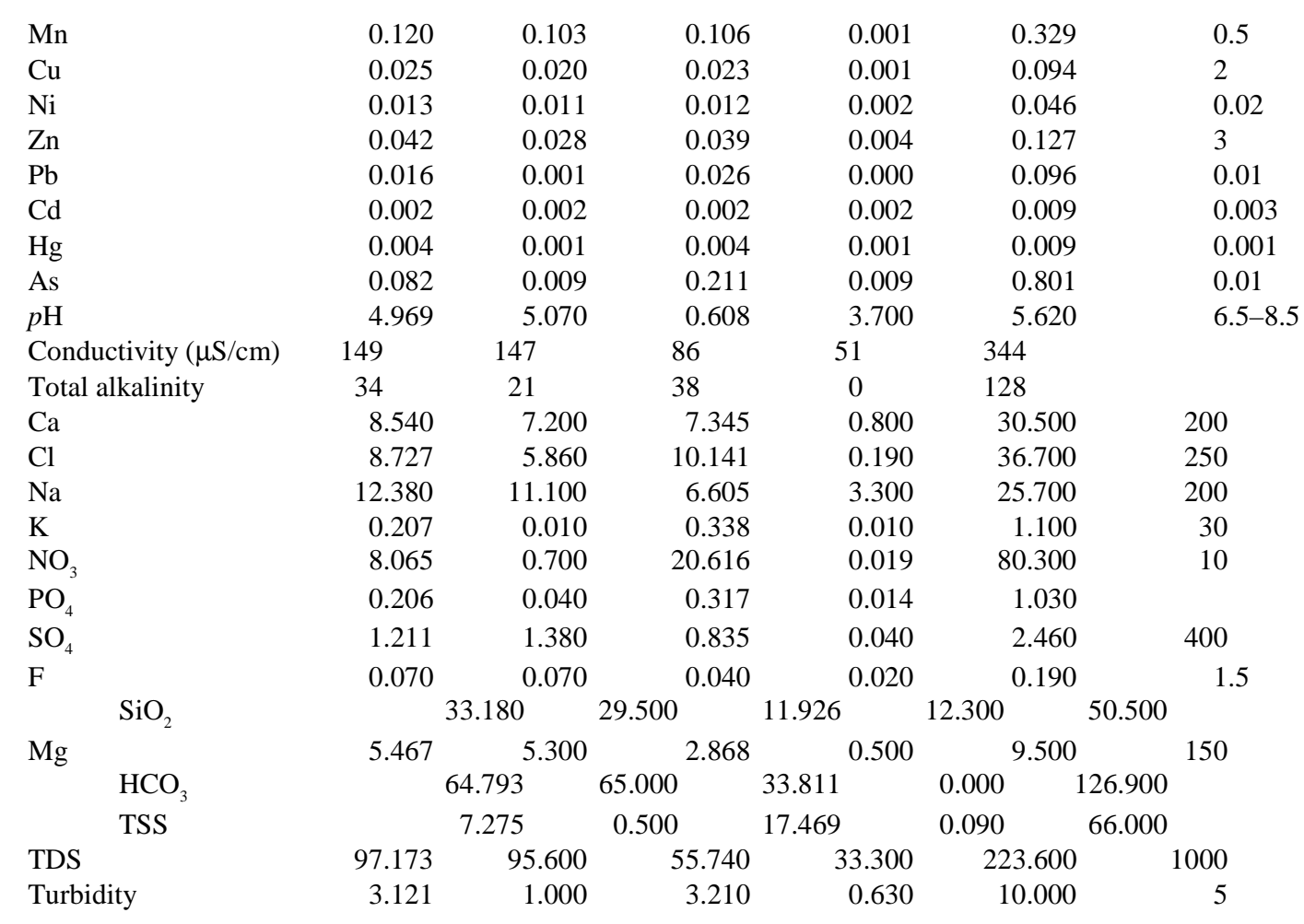

Number of samples $=13$

Asernic values are above the WHO guide values in all streams including The Fena at Adaase, Hia No. 2 and Faaman, all upstream of mining and processing facilities. However, the highest concentration of arsenic in streams were recorded immediate down-stream of mining and processing facilities. Iron values in streams range from $0.0259 \mathrm{mg} / \mathrm{l}$ at Adaase to $17.19 \mathrm{mg} / \mathrm{l}$ at Kwabrafoso while arsenic ranged from $<0.001 \mathrm{mg} / \mathrm{l}$ at Adaase to $18.91 \mathrm{mgl} / \mathrm{l}$ at Kwabrafoso (Table 2). The arsenic concentration in streams within the vicinity of mine facilities in the study area of up to $18.91 \mathrm{mg} / \mathrm{l}$ is considerably higher than the average range of As in typical arsenopyrite bearing gold ore, globally estimated between several $\mu \mathrm{g} / \mathrm{l}$ to $100 \mu \mathrm{g} / \mathrm{l}$ (Dinelli \& Tateo, 2001). Major ion concentrations in streams exhibit similar patterns as trace ions discussed above.

TABLE 2

Water quality parameter status in streams $(\mathrm{mg} / \mathrm{l})$

\begin{tabular}{|c|c|c|c|c|c|c|}
\hline Parameter & Mean & Median & $\begin{array}{l}\text { Standard } \\
\text { deviation }\end{array}$ & Min. & $\operatorname{Max}$ & $\begin{array}{l}\text { WHO max. } \\
\text { guide value }\end{array}$ \\
\hline $\mathrm{Fe}$ & 5.032 & 3.642 & 5.258 & 0.259 & 17.190 & 0.3 \\
\hline Mn & 0.758 & 0.464 & 0.777 & 0.146 & 2.584 & 0.5 \\
\hline $\mathrm{Cu}$ & 0.023 & 0.020 & 0.024 & 0.000 & 0.086 & 2 \\
\hline $\mathrm{Ni}$ & 0.025 & 0.015 & 0.022 & 0.003 & 0.058 & 0.02 \\
\hline $\mathrm{Zn}$ & 0.034 & 0.022 & 0.035 & 0.003 & 0.120 & 3 \\
\hline $\mathrm{Pb}$ & 0.014 & 0.003 & 0.021 & 0.001 & 0.057 & 0.01 \\
\hline $\mathrm{Cd}$ & 0.002 & 0.002 & 0.000 & 0.002 & 0.002 & 0.003 \\
\hline $\mathrm{Hg}$ & 0.008 & 0.009 & 0.005 & 0.001 & 0.018 & 0.001 \\
\hline As & 3.137 & 0.291 & 5.903 & 0.009 & 18.910 & 0.01 \\
\hline$p \mathrm{H}$ & 6.678 & 6.665 & 1.041 & 4.660 & 8.330 & $6.5-8.5$ \\
\hline Cond $(\mu \mathrm{S} / \mathrm{cm})$ & 389.000 & 376.500 & 233.049 & 126.000 & 847.000 & \\
\hline Tot. alkalinity & 24.710 & 0.000 & 33.431 & 0.000 & 87.000 & \\
\hline
\end{tabular}




\begin{tabular}{|c|c|c|c|c|c|c|}
\hline $\mathrm{Ca}$ & 26.360 & 15.600 & 23.454 & 8.000 & 75.400 & 200 \\
\hline $\mathrm{Cl}$ & 14.560 & 11.600 & 7.148 & 7.780 & 27.000 & 250 \\
\hline $\mathrm{Na}$ & 24.340 & 16.950 & 18.121 & 5.900 & 60.500 & 200 \\
\hline $\mathrm{K}$ & 10.940 & 9.550 & 7.974 & 2.300 & 27.000 & 30 \\
\hline $\mathrm{NO}_{3}$ & 0.144 & 0.035 & 0.286 & 0.010 & 0.940 & 10 \\
\hline $\mathrm{PO}_{4}$ & 0.544 & 0.090 & 0.904 & 0.014 & 2.800 & \\
\hline $\mathrm{SO}_{4}$ & 76.121 & 59.550 & 71.452 & 3.000 & 240.000 & 400 \\
\hline $\mathrm{F}$ & 0.053 & 0.050 & 0.024 & 0.020 & 0.100 & 1.5 \\
\hline $\mathrm{SiO}^{2}$ & 21.140 & 21.350 & 4.021 & 13.100 & 26.600 & \\
\hline $\mathrm{Mg}$ & 11.930 & 8.500 & 10.988 & 2.400 & 33.400 & 150 \\
\hline $\mathrm{HCO}_{3}$ & 112.120 & 111.550 & 68.054 & 19.500 & 258.600 & \\
\hline TSS & 344.550 & 66.500 & 866.406 & 1.500 & 2799.000 & \\
\hline TDS & 252.870 & 244.750 & 151.488 & 81.900 & 550.600 & 1000 \\
\hline Turbidity & 106.925 & 41.500 & 154.230 & 3.000 & 501.000 & 5 \\
\hline
\end{tabular}

Elevated values of $\mathrm{Mg}, \mathrm{Ca}, \mathrm{SO}_{4}, \mathrm{HCO}_{3}$ are observed in samples from streams immediately down stream of mining and processing facilities at Kwabrafoso, Binsere, Dokyiwa and Sansu. The strong spatial variation in the concentration of measured parameters is reflected in the standard deviations presented in Tables 1 and 2.

Generally, major ions from stream samples show strong moderate to positive correlation with As, $\mathrm{Mn}, \mathrm{Cu}, \mathrm{Ni}$, and $\mathrm{Zn}$. According to $\mathrm{Zhu}$ et al. (2003), such positive correlation of arsenic and heavy metals with major ions provide evidence that arsenic and these trace ions are likely derived locally from the water-mineralized rock interaction. This suggests that they are products of dissolution of host minerals occurring together. As pointed out by Plumlee et al. (1999), the concentration of individual elements in drainage waters, in part, reflect the elements' abundance in the geological units being drained. Price \& Errington (1998) also confirmed that such high concentrations of trace ions such as $\mathrm{Mn}, \mathrm{Cu}, \mathrm{Ni}, \mathrm{Zn}$ and $\mathrm{As}$ in neutral $p \mathrm{H}$ drainage, as exhibited in this study, results from localized acid generating sources.

Elevated metal leaching is usually associated with acidic drainage due to high metal solubility and sulphide weathering rates under acidic conditions. Alkaline earth carbonates such as calcite, dolomite, ankerite and magnesite typically react to produce elevated $\mathrm{Ca}, \mathrm{Mg}$ and $\mathrm{HCO}_{3^{-}}$ concentrations. The elevated trace ions, sulphate concentrations, total dissolved solids and electrical conductivity within the vicinity of mining facilities and the very strong correlation among these parameters are strong indication of water quality degradation related to mining (Bell et al., 2002).

The defining impact of these elevated major ions on the waters in the area is amplified in the Piper trilinear plot of major ions in groundwater and surface water in the study area (Piper, 1944) (Fig. 2). The exact chemical composition of these waters modeled from Aqua Chem 3.70 is presented in Table 3. The waters in the area are dominated by $\mathrm{Ca}^{2+}-\mathrm{Mg}^{2+}-\mathrm{Na}^{+}-\mathrm{HCO}_{3}^{-}$and $\mathrm{Ca}^{2+}-$ $\mathrm{Mg}^{2+}-\mathrm{Na}^{+}-\mathrm{HCO}_{3}{ }^{-}-\mathrm{SO}_{4}{ }^{2}$ dominant waters, with variations in the preponderance of the $\mathrm{Mg}, \mathrm{Ca}$ and $\mathrm{Na}$ ions. The overall chemical composition of the water reflects the geology and mineral assemblages in the area. Such a menu of mixed ions in stream water as presented in Table 3 is certainly an indication of mixing of water, and, according to Hem (1985), that would likely be produced by the dissolution of silicates, sulphides and carbonates.

TABLE 3

Chemical composition of waters from the study area

Water source Community Water type 


$\begin{array}{lll}\text { Borehole \#1 } & \text { Adaasi } & \mathrm{Mg}-\mathrm{Ca}-\mathrm{SO}_{4} \\ \text { Borehole \#2 } & \text { Adaasi } & \mathrm{Na}-\mathrm{Mg}-\mathrm{Ca}-\mathrm{HCO}_{3} \\ \text { Borehole\#1 } & \text { Akatakyieso } & \mathrm{Na}-\mathrm{Mg}-\mathrm{Ca}-\mathrm{HCO}_{3} \\ \text { Borehole \#2 } & \text { Akatakyieso } & \mathrm{Na}-\mathrm{Mg}-\mathrm{Ca}-\mathrm{HCO}_{3} \\ \text { Borehole } & \text { Dokyiwa } & \mathrm{Mg}-\mathrm{HCO}_{3} \\ \text { Borehole \#1 } & \text { New Bidiem } & \mathrm{Ca}-\mathrm{Na}-\mathrm{Mg}-\mathrm{HCO}_{3} \\ \text { Borehole \#2 } & \text { New Bidiem } & \mathrm{Mg}-\mathrm{Na}-\mathrm{Ca}-\mathrm{HCO}_{3} \\ \text { Borehole \#1 } & \text { Ntonsua } & \mathrm{Na}-\mathrm{Mg}-\mathrm{Ca}-\mathrm{HCO}_{3} \\ \text { Borehole \#2 } & \text { Ntonsua } & \mathrm{Na}-\mathrm{HCO} \\ \text { Borehole } & \text { Amamon } & \mathrm{Na}-\mathrm{Ca}-\mathrm{Mg} \\ \text { Hand dug well } & \text { Hia \#1 } & \mathrm{Na}-\mathrm{Ca}-\mathrm{HCO} \\ \text { Hand dug well } & \text { Hia \#2 } & \mathrm{Ca}-\mathrm{Na}-\mathrm{Mg}-\mathrm{HCO}_{3}-\mathrm{C} \\ \text { Hand dug well } & \text { Fenaaso } & \mathrm{Na}-\mathrm{K}-\mathrm{Ca}-\mathrm{HCO}_{3}-\mathrm{SO}_{4} \\ \text { River Fena } & \text { Fenaaso } & \mathrm{Na}-\mathrm{K}-\mathrm{Ca}-\mathrm{HCO}_{3} \\ \text { River Fena } & \text { Hia \#2 } & \mathrm{Na}-\mathrm{Ca}-\mathrm{Cl}-\mathrm{HCO}_{3} \\ \text { River Jimi } & \text { Jimiso } & \mathrm{Ca}-\mathrm{Mg}-\mathrm{Na}-\mathrm{HCO}_{3}-\mathrm{C} \\ \text { R. Kwabrafo } & \text { Kwabrafoso } & \mathrm{Ca}-\mathrm{Mg}-\mathrm{SO}_{4}-\mathrm{HCO}_{3} \\ \text { R. Kwaab } & \text { Kwabrafoso } & \mathrm{Ca}-\mathrm{Mg}-\mathrm{Cl}_{-}-\mathrm{HCO}_{3} \\ \text { R. Supu } & \text { Ntonsua } & \mathrm{Na}-\mathrm{Ca}-\mathrm{Mg}-\mathrm{HCO}_{3} \mathrm{SO}_{4} \\ \text { R. Fena } & \text { Adaasi } & \mathrm{Na}-\mathrm{Ca}-\mathrm{Mg}-\mathrm{HCO}_{3} \\ \text { R. Kwami } & \text { Dokyiwa } & \mathrm{Na}-\mathrm{Ca}-\mathrm{SO}_{4}-\mathrm{HCO}_{3} \\ \text { River San } & \text { Sansu } & \mathrm{Ca}-\mathrm{Mg}-\mathrm{HCO}_{3}-\mathrm{SO}_{4} \\ & & \end{array}$

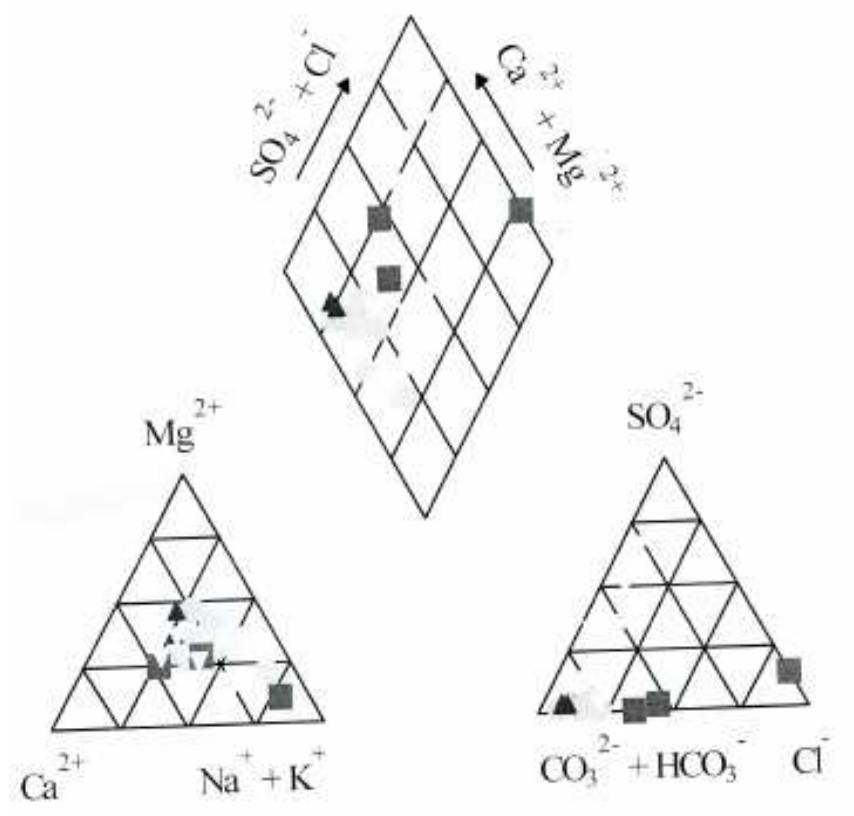

Fig. 2. Piper trilinear plot of waters in the study area

The $\mathrm{Mg}$ and $\mathrm{Ca}$ ions are likely derived from carbonates, mainly siderite and ferroan dolomite, which form a significant component of the mineralogy of the rocks in the area (Hirdes \& Leube, 1989). However, the $\mathrm{Mg}$ and $\mathrm{Ca}$, together with $\mathrm{Na}$ ions, could also have come from the dissolution of the silicates. $\mathrm{HCO}_{3}$ - ions, could come from reduction of sulphate (from oxidation of 
sulphides) and root zone material by microbial activities. The area has substantial sulphides, especially pyrite and arsenopyrite, the oxidation of which could contribute $\mathrm{SO}_{4}^{2}$ - ions to the waters. The chloride could be from anthropogenic sources and the intrusive rocks typified by granitoids in the area. The carbon is most likely from the graphic schist metsedimentary sequences. In fact, Gyapong (1980) states that graphic schist at the Ashanti mines contain, on average, $4 \%$ elemental carbon.

Evidence of water degradation due to mining is from the fact that while there is augmented concentrations of major and trace ions in water samples from Kwabrafoso, Tutuka, Dokyiwa and Sansu, all proximal to mine facilities, there is attenuation of the concentration of the parameters in streams further away from, and upstream of mining and processing facilities. The concentration of major and trace ions in samples from Amaamo, Fenaase and Adaase, all upstream of mining and processing facilities, are highly subdued and rarely exceed the WHO guide values of the measured ions in waters from these communities. Similarly, a sample from the Jimi river, which also takes drainge from the other streams distal to mining activities, are relatively low due largely to dilution and sequestering of these elements in sediments.

\section{Sources of metals in waters}

The spatial correlation between augmented metal concentrations, and mining and processing facilities, and mine spoil sites suggest that mine waste sites constituent sources of these metals in drainage water. Microprobe analysis of rock samples taken from rock waste dumps and exposed outcrops in the area show that the waste rocks contain a variety of base metal and metalloidbearing sulphides, together with carbonates (calcite, dolomite, ankerite, siderite), silicates and oxides. The analysis showed that sulphides content in waste rock samples ranged between $0.01 \%$ and $3.86 \%$ while carbonates ranged from $0.01 \%$ to $15 \%$. This study put emphasis on the analysis of sulphides because they constitute the principal custodians of the toxic metals analysed in water samples. The probe results show that sulphides exhibit strong compositional variation defined by their relative trace element content. $\mathrm{Fe}, \mathrm{As}, \mathrm{Cu}, \mathrm{Ni}, \mathrm{Zn}, \mathrm{Sb}$ and Co-bearing varieties constitute the dominant sulphides. Table 4 shows the compositional variations of pyrite, arsenopyrite, chalcopyrite, sphalerite, ullmannite and gersdorffite in probed mineral grains in rock samples taken from mine spoil.

From the menu of trace metals and major ions observed in water and the compositional complexity of the observed sulphides in the rocks, it can be deduced that the weathering of these sulphide-bearing rocks, greatly facilitated by mining, accounts for the elevated ions in the water in the vicinity of the mining and processing facilities. According to Larocque \& Rasmussen (1998), mine spoil, especially tailings environments are the sites of metal flux from the geosphere to the hydrosphere through dissolution of minerals. The exposure of rock strata to the atmosphere (air and water) promotes oxidation of the sulphides, leading to the discharge of the contained metals into local drainage. According to Plumlee et al. (1999), schematically, the following reactions can take place to generate these ions under typical surface weathering conditions:

$$
\begin{aligned}
& (\mathrm{Fe}, \mathrm{Me}) \mathrm{S}_{2}+5 / 2 \mathrm{O}_{2}+2 \mathrm{H}^{+}=\mathrm{Fe}^{2+}{ }_{\text {aq }}+\mathrm{Me}^{2+}{ }_{\text {aq }}+2 \mathrm{SO}_{4}{ }^{2-}+\mathrm{H}^{+} \\
& 2 \mathrm{Fe}^{2+}{ }_{\text {aq }}+1 / 2 \mathrm{O}_{2}+2 \mathrm{H}^{+}=2 \mathrm{Fe}^{3+}{ }_{\text {aq }}+\mathrm{H}_{2} \mathrm{O}
\end{aligned}
$$

TABLE 4

Results of microprobe analyses (in atomic \%) of various sulphides in rock samples

$\begin{array}{lcccccccccccc}\text { Mineral } & S & M n & N i & \text { As } & \text { Fe } & \text { Sb } & \text { Zn } & \text { Co } & \text { Cu } & \text { Total } & n^{l} \\ & & & & & & & & & & & & \\ \text { Sphalerite } & & & & & & & & & & & \\ \text { Min }(\mathrm{Cu}) & 46.06 & 0.10 & - & 0.04 & 9.68 & - & 43.89 & - & - & 98.77 & \\ \text { Max }(\mathrm{Cu}) & 50.20 & 0.01 & 0.02 & 0.03 & 2.75 & - & 46.97 & - & 0.03 & 100.01 & 12 \\ \text { Average } & 51.83 & 0.02 & 0.01 & 0.02 & 2.83 & - & 44.11 & - & 1.05 & 99.87 & \end{array}$




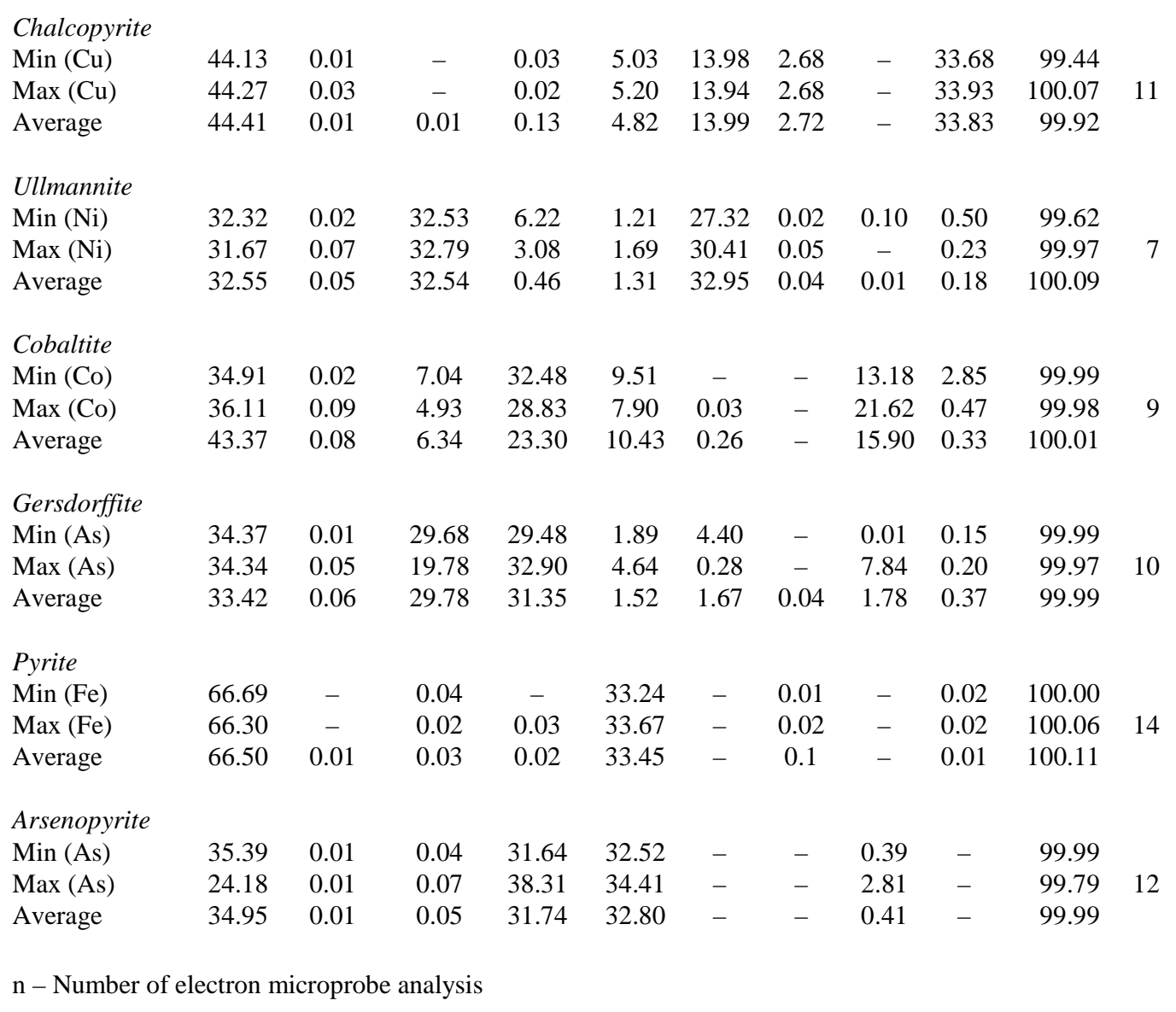

( $\mathrm{Fe}, \mathrm{Me}) \mathrm{S}_{2}$ could be pyrite, chalcopyrite, bornite or arsenopyrite. The oxidation of $\mathrm{Fe}^{2+}$ to $\mathrm{Fe}^{3+}$ would enable the aggressive oxidation of other metal sulphides with metal to sulphide ratio less than 1, which would normally not be affected by the oxidation reaction in equation 1 (Evangelou, 1995). This would have been the most likely dissolution mechanisms for sphalerite, ullmannite and gersdorffite minerals identified in this study. The carbonate minerals present will usually react with the acid solution generated from equations 1 and 2 according to the generalized neutralization reaction:

$\mathrm{MeCO}_{3}^{+} \mathrm{H}^{+}=\mathrm{Me}^{2+}{ }_{\text {aq }}+\mathrm{HCO}_{3-}^{-}{ }_{\text {aq }}$

$\mathrm{MeCO}_{3}$ could be calcite, dolomite, ankerite, siderite or magnesite.

Both acid producing and consuming reactions as schematized above would typically generate constituents such as the metals, sulphate and bicarbonates into solution, and transform others into stable constituents in sediments, as observed in the waters from the study site. Thus, these oxidation and neutralization processes, together with other possible weathering reactions involving silicates and oxides within the mine spoil would generate the menu of trace and major ions in the drainage waters while similar reactions from wall rock/water interactions and seepage will account for high level of metals encountered in some of the boreholes.

\section{Conclusion}


The results show that past and present large scale and illegal small-scale mining activities have affected water resources in Obuasi and its satellite communities. Stream water is significantly polluted by $\mathrm{As}, \mathrm{Hg}, \mathrm{Fe}$, and, to some extent, $\mathrm{Cu}, \mathrm{Ni}$ and $\mathrm{Zn}$. Groundwater is quite benign and rarely exceeded the WHO guide values for portable water with respect to major and trace element concentration. Microprobe mapping of sulphide grains in rock samples showed a variety of $\mathrm{Cu}$, $\mathrm{As}, \mathrm{Ni}$ and $\mathrm{Zn}$ bearing sulphides as possible sources of augmented concentrations of these pollutants in water. The strong correlation among $\mathrm{Cu}$, $\mathrm{As}, \mathrm{Ni}$ and $\mathrm{Zn}$ in both water and the significant occurrence of the respective sulphides in the country rock and waste rocks confirm that the weathering of these materials provided these pollutants in the water and sediments.

\section{Acknowledgement}

The authors wish to express sincere gratitude to Third World Network Africa Secretariat and the DANIDA-ENRECA Hydrogeological Project, for providing the financial support for the study.

\section{References}

APHA, AWWA, WEF (1998). Standard methods for the examination of water and wastewater, 20 th edn. APHA/AWWA/WEP, Washington, D.C., New York.

Amonoo-Neizer E. H. and Busari G. L.(1980). Arsenic status of Ghana soils- Contamination of soils near gold smelters. Ghana J. Sci. 20 (1\&2): 57-62.

Bell F. G., De Brulyn L. A. and Stacey T. R. (2002). Some examples of the impacts of metalliferous mining on the environment: a South African perspective. Bull. Engng Envir. Geol. 61: 1-20.

Bowell B. J. (1993). Mineralogy and geochemistry of tropical rainforest soils: Ashanti, Ghana. Chem. Geol. 106: 345358.

Carboo D. and Sarfo-Armah Y. (1997). Arsenic pollution in stream sediments in the Obuasi area. Proceedings of the Symposium on the Mining Industry and the Environment. KNUST/IDRC 1997. 114-119.

Clement C., Asmah R. Addy M. E., Bosompem K. M. and Akanmori B. D. (1997). Local sulphooxidizing bacteria for environmentally friendly gold mining. Proceedings of the Symposium on the mining industry and the environment, .KNUST/IDRC 1997. pp. 120-122.

Dinelli E. and Tateo F. (2001). Factors controlling heavy metal despersion in mining areas: the case of Vigonzano (Northern Italy), a Fe-Cu sulphide deposit associated with ophiolitic rocks. Envir. Geol. 40: 1135-1150.

Eppinger R. G., Briggs P. H., Rosenkrans D. and Ballestrazze V. (1999). Environmental Geochemical Studies of Selected mineral deposits in Wrangell - St Elias National Park and preserve, Alaska. USGS Professional Paper 1619. $41 \mathrm{pp}$.

Evangelou V. P. (1995). Pyrite oxidation and its control: Solution chemistry, Surface Chemistry, Acid Mine Drainage $(A M D)$, Molecular oxidation mechanisms, Microbial role, Kinetics, Control, Amelioration and Limitations, Microencapsulation. CRS Press Inc. 293 pp.

Gyapong W. A. (1980). Factors controlling ore localization. (Masters Thesis.) Imperial College, London. pp. 90150.

Gyapong W. and Manor R. (2003). Gold mineralisation in the Obuasi Mine. Unpublished briefing notes for students of the department of Geology, University of Ghana, Legon.

Hem J. D. (1985). Study and interpretation of the chemical characteristics of natural water. U.S. Geological Survey Water Supply Paper 2254. 263 pp.

Hirdes W. and Leube A. (1989). On gold mineralisation of the proterezoic Birimian supergroup in Ghana/West Africa. Ghana-German Mineral Prospecting Project. pp. 27-49.

Jetuah F. ( 1997). Production of sulphuric acid from flue gases of Prestea and Obuasi gold mines. In Proceedings of the Symposium on the Mining Industry and the Environment. KNUST/IDRC 1997. pp. 139-144.

Junner N. R. (1932). Geology of the Obuasi Goldfield. Gold Coast Geol. Surv. Mem. 2. 77 pp.

Kesse G. O. (1985). The mineral and rock resources of Ghana. Balkema, Rotterdam.

Larocque A. C. L. and Rasmussen P. E. (1998). An overview of trace metals in the environment, from mobilization to remediation. Envir. Geol. 33 (2/3): 85-91.

Piper A. M. (1944). A graphic procedure in the geochemical interpretation of water Analyses. Am. Geophys. Un. Trans. pp. 914-923.

Plumlee S. G., Smith, K. S., Montour W. H., Ficklin W. H., and Mosier E. L. (1999). Geologic controls on the composition of natural eaters and mine waters draining diverse mineral deposits types. In The Environmental Geochemistry of Mineral deposits, Part B: Processes, Techniques and Health Issues. (H. L. Filipek and S. G. Plumlee, ed.), pp. 373-409. Society of Economical Geologists Inc.

Price W. A. and Errington J. C. (1998). Guidelines for Metal Leaching and Acid Mine/Rock Drainge at Mines Sites in British Columbia. Ministry of Employment and Investment, Canada. 141 pp. 
Zhu Y., Merkel B. J., Stober I., Bucher K. (2003). The hydrology of arsenic in the Clara mine, Germany. Mine Wat. Envir. 22:110-117. 